\title{
Vasopressin and hyperosmolality regulate NKCC1 expression in rat OMCD
}

\author{
Shiho Wakamatsu ${ }^{1}$, Hiroshi Nonoguchi ${ }^{2}$, Mika Ikebe $^{1}$, Kenji Machida ${ }^{1}$, Yuichiro Izumi ${ }^{1}$, Hasiyet Memetimin ${ }^{1}$, \\ Yushi Nakayama ${ }^{1}$, Takeshi Nakanishi ${ }^{2}$, Yukimasa Kohda ${ }^{1}$ and Kimio Tomita ${ }^{1}$
}

Secretory-type Na-K-2Cl cotransporter (NKCC1) is known to play roles in both acid and sodium excretion, and is more abundant in dehydration. To determine the mechanisms by which dehydration stimulates NKCC1 expression, the effects of vasopressin, oxytocin and hyperosmolality on NKCC1 mRNA and protein expressions in the outer medullary collecting duct (OMCD) of rats were investigated using RT-competitive PCR and western blot analysis. Microdissected OMCD was incubated in isotonic or hypertonic solution, or with AVP or oxytocin for $60 \mathrm{~min}$ at $37^{\circ} \mathrm{C}$. Hyperosmolality induced by $\mathrm{NaCl}$, mannitol or raffinose increased NKCC1 mRNA expression in OMCD by $130-240 \%$ in vitro. The stimulation of NKCC1 mRNA expression by NaCl was highest at 690 mosmol kg-1 $\mathrm{H}_{2} \mathrm{O}$ and gradually decreased at higher osmolalities. The incubation of OMCD with AVP $\left(10^{-7} \mathrm{M}\right)$ for $60 \mathrm{~min}$ increased NKCC1 mRNA expression by $100 \%$. The administration of AVP to rats for 4 days using an osmotic mini-pump also increased NKCC1 mRNA and protein expressions in OMCD by $130 \%$. In contrast, oxytocin $\left(10^{-7} \mathrm{M}\right)$ did not stimulate the NKCC1 mRNA expression in OMCD in vitro. Chronic injection of oxytocin increased the NKCC1 mRNA expression by $36 \%$. These data showed that hyperosmolality and vasopressin stimulate NKCC1 mRNA and protein expressions in rat OMCD. It is concluded that NKCC1 expression is regulated directly and indirectly by vasopressin.

Hypertension Research (2009) 32, 481-487; doi:10.1038/hr.2009.52; published online 24 April 2009

Keywords: dehydration; mRNA; NKCC1; RT-competitive PCR; vasopressin

\section{INTRODUCTION}

The main role of the kidney is to maintain body fluid homeostasis by excreting or reabsorbing water and electrolytes. The $\mathrm{Na}-\mathrm{K}-2 \mathrm{Cl}$ cotransporters are electrically neutral transporters with a stoichiometry of $1 \mathrm{Na}, 1 \mathrm{~K}$ and $2 \mathrm{Cl}$, and are known to play key roles in maintaining sodium balance. ${ }^{1}$ Two types of Na-K-2Cl cotransporters have been cloned. ${ }^{2-4}$ NKCC2 (bumetanide-sensitive cotransporter 1; BSC1) is localized only in the thick ascending limbs of the kidney and participates in sodium reabsorption. ${ }^{2}$ The blockade of NKCC2 by furosemide causes potent diuresis and natriuresis. In contrast, NKCC1 (BSC2) is widely distributed throughout the body, and is especially abundant in the salivary glands, colon and kidney. ${ }^{3-7}$ NKCC1 participates in sodium secretion in the salivary glands and in ammonium secretion in the kidney. ${ }^{5,8}$ NKCC1 protein is mainly located in the basolateral membrane of the $\alpha$-intercalated cells of the outer medullary collecting duct (OMCD). ${ }^{7}$ We have reported that NKCC1 expression was stimulated by a 2 -day dehydration and by chronic metabolic acidosis. ${ }^{9}$

Vasopressin is one of the most important hormones that regulate body fluid homeostasis. V2 vasopressin receptors are localized in the distal nephron segments. ${ }^{10}$ In dehydration, the plasma concentration of vasopressin and plasma osmolality are known to increase. Lack of either V2 receptors or aquaporin 2 causes nephrogenic diabetes insipidus. ${ }^{11}$ NKCC2 activity and expression is regulated by vasopres$\sin ^{12}$ It has also been reported that NKCC1 activity, measured by bumetanide-sensitive ${ }^{86} \mathrm{Rb}$ uptake, was stimulated by vasopressin in cultured vascular endothelial cells and in cultured fibroblasts. ${ }^{13,14}$ However, the precise mechanisms of regulation of NKCC1 expression by vasopressin are not known.

NKCC1 is also activated by hypertonicity-induced cell shrinkage in Ehrlich ascitis cells and in duck red blood cells. ${ }^{15-17}$ Lytle and Forbush ${ }^{18}$ reported that reduced intracellular chloride concentration ([Cl]i) is the signal for NKCCl activity in shark rectal glands. ${ }^{18}$ Under normal circumstances, OMCD exists in a hypertonic condition. The osmolality in the medullary interstitium varies dramatically depending on water intake and excretion. But it is not known whether hypo- or hyperosmolality activates acutely the NKCC1 expression in OMCD.

To determine the mechanisms by which dehydration stimulates NKCC1 expression, we investigated the acute and chronic effects of vasopressin and hyperosmolality on NKCC1 mRNA and protein expressions in OMCD using RT-competitive PCR and western blot analysis.

${ }^{1}$ Department of Nephrology, Kumamoto University Graduate School of Medical Sciences, Honjo, Kumamoto, Japan and ${ }^{2}$ Division of Kidney and Dialysis, Department of Internal Medicine, Hyogo College of Medicine, Mukogawa-cho, Nishinomiya, Hyogo, Japan 


\section{MATERIALS AND METHODS}

\section{Materials}

$\left[\mathrm{Arg}^{8}\right]$-vasopressin (AVP), oxytocin and collagenase were obtained from Sigma (St Louis, MO, USA). The competitive DNA construction kit was obtained from Takara (Shiga, Japan) and CDNA synthesis and PCR master were purchased from Roche Molecular Biochemicals (Mannheim, Germany). Pathogen-free male Sprague-Dawley rats weighing $80-100 \mathrm{~g}$ were obtained from Seac (Fukuoka, Japan). All rats were given free access to tap water or a $5 \%$ glucose solution (infusion study) and fed a standard pellet diet. The protocol of our experiments was reviewed and approved by the committee of the Kumamoto University Institute of Resource Development and Analysis (no. 16-63, 17-13, 18-127 and 19-63). Urine osmolality was measured using an osmometer (Fiske, Norwood, MA, USA). Serum sodium and chloride concentrations were measured using an autoanalyzer (Hitachi, Tokyo, Japan). The plasma AVP concentration was measured by radioimmunoassay (SRL laboratory, Tokyo, Japan).

\section{Vasopressin or oxytocin infusion study}

A long-term subcutaneous infusion study of $\left[\mathrm{Arg}^{8}\right]$-vasopressin or oxytocin was carried out for 4 days. Under pentobarbital anesthesia, the rats were implanted subcutaneously with osmotic mini-pumps (model 2002; Alzet, Palo Alto, CA, USA) that delivered 1.67 and $111 \mathrm{ng} \mathrm{h}^{-1}$ per $100 \mathrm{~g}$ body weight of vasopressin and oxytocin, respectively. In the case of control rats, the minipumps delivered saline. After 4 days, the kidneys from the vasopressin or oxytocin-infused and control rats were removed after the anesthesia that was used in the experiments described below.

Blood pressure during vasopressin and oxytocin infusion was measured using the tail-cuff method. BP-98A and THC-31 (recorder and cuff, respectively, Softron, Tokyo, Japan) were used for the blood pressure measurements. The average of three consecutive measurements was used as a single value of measured blood pressure.

\section{Microdissection}

Microdissection of OMCD was carried out as described earlier. ${ }^{9,19-21}$ In brief, after anesthetizing the rats by intraperitoneal administration of pentobarbital ( $5 \mathrm{mg}$ per $100 \mathrm{~g}$ body weight), the left kidney was perfused with $10 \mathrm{ml}$ of solution A (in mm: $130 \mathrm{NaCl}, 5 \mathrm{KCl}, 1 \mathrm{NaH}_{2} \mathrm{PO}_{4}, 1 \mathrm{MgSO}_{4}, 1$ calcium lactate, 2 sodium acetate, 5.5 glucose and 10 Hepes; 290 mosmol kg-1 $\mathrm{H}_{2} \mathrm{O}$; pH 7.4). The kidney was then excised and sliced coronally, and the slices were placed into solution A containing $1 \mathrm{mg} \mathrm{ml}^{-1}$ type I collagenase and $10 \mathrm{mM}$ VRC (New England Bio labs, Beverly, MA, USA) as an RNase inhibitor. After incubation at $37^{\circ} \mathrm{C}$ for $30 \mathrm{~min}$, the slices were washed in solution A containing $10 \mathrm{~mm}$ VRC, and microdissected under a stereomicroscope. The OMCD was isolated and measured by a calibrated eyepiece micrometer. OMCD of $2 \mathrm{~mm}$ and of $15-25 \mathrm{~mm}$ in length were used for reverse transcriptase-competitive PCR (RT-competitive PCR) and western blotting, respectively. After microdissection, the samples were briefly washed in solution A.

\section{Incubation study}

In the incubation study, the microdissected OMCD was placed in Eppendorf tubes. An experiment using a hypertonic solution was carried out as described earlier. ${ }^{20,21}$ To determine the time course of the stimulation of the NKCC1 mRNA expression by hyperosmolality, a solution of 690 mosmol kg-1 $^{-1} \mathrm{H}_{2} \mathrm{O}$ (solution A plus $\mathrm{NaCl}$ ) was added and the samples were incubated at $37^{\circ} \mathrm{C}$ for 30 to $240 \mathrm{~min}$. Next, to determine the maximal effect of hyperosmolality, the samples were incubated at $37^{\circ} \mathrm{C}$ for $60 \mathrm{~min}$ in solutions having various osmolalities, which were established by adding $\mathrm{NaCl}$ or water $(145,290$ (control), 490, 690, 890 and 1090 mosmol kg-1 $\mathrm{H}_{2} \mathrm{O}$ ). To achieve osmolalities of 690 mosmol kg-1 $\mathrm{H}_{2} \mathrm{O}$, mannitol and raffinose were also added.

Next, the direct effect of vasopressin on NKCC1 mRNA expression was investigated by incubation of OMCD for $60 \mathrm{~min}$ at $37^{\circ} \mathrm{C}$ in solution $\mathrm{A}$ containing vasopressin. Vasopressin was diluted with solution A to various concentrations $\left(10^{-10}, 10^{-9}, 10^{-8}\right.$ and $\left.10^{-7} \mathrm{M}\right)$. Finally, the direct effect of oxytocin on NKCC1 mRNA expression was examined; oxytocin was also diluted with solution $\mathrm{A}$.

\section{Preparation of oligonucleotide primers and competitors}

Specific PCR primers were designed as follows: The primer sequence for NKCCl corresponded to $5^{\prime}$-GGT TCT CCA AAC TCA CGG CC-3' (sense; bases 2486-2505) and 5'-GTC TTG CCA TCC TCT TCC TC-3' (antisense; bases $3032-3051) .^{22}$ The final PCR product was $566 \mathrm{bp}$ in size. Sense and antisense primers for glyceraldehyde 3-phosphate dehydrogenase (GAPDH) were defined as $5^{\prime}$-TCCCTCAAGATTGTCAGCAA-3' (bases 506-525) and $5^{\prime}$-AGATCCACAACGGATACATT-3' (bases 794-813). The predicted length of amplified cDNA was $308 \mathrm{bp}$ in length. ${ }^{23}$

The DNA competitor for NKCC1 was prepared using a cDNA construction kit (Takara). The primer sequence for the NKCC1 competitor corresponded to 5'-GGT TCT CCA AAC TCA CGG CCG TAC GGT CAT CAT CTG ACA C-3' (sense) and 5'-GTC TTG CCA TCC TCT TCC TCC AAA ACT CAA CGA GCA GCG T- $3^{\prime}$ (antisense). The length of the competitor was $456 \mathrm{bp}$. The DNA competitor for GAPDH was directly prepared ( $100 \mathrm{bp}$ : from bases $506-555$ and 764-813; 5'-TCC CTC AAG ATT GTC AGC AAT GCA TCC TGC ACC ACC AAC TGC TTA GCC CCC CTG GCA TGG CCT TCC GTG TTC CTA CCC CCA ATG TAT CCG TTG TGG ATC T-3').

\section{RT-competitive PCR}

RT-competitive PCR was carried out as described earlier. ${ }^{9,19-21}$ In brief, sample tubes were centrifuged for $5 \mathrm{~min}$ at $4^{\circ} \mathrm{C}$ after incubation. After aspiration of the supernatant, an RT master mix containing $20 \mathrm{U}$ reverse transcriptase, AMV, $16 \mathrm{U}$ RNase inhibitor (cDNA synthesis kit) and triton-X100 (Sigma) were added. RT was carried out at $42^{\circ} \mathrm{C}$ for $60 \mathrm{~min}$, and stopped by incubation at $90^{\circ} \mathrm{C}$ for $5 \mathrm{~min}$. PCR reaction mixes were added to each sample, and the NKCC1 and GAPDH cDNAs were amplified. PCR consisted of 29 cycles of denaturing at $94^{\circ} \mathrm{C}$ for $1 \mathrm{~min}$, annealing at $60^{\circ} \mathrm{C}$ for $1 \mathrm{~min}$ and extension at $72^{\circ} \mathrm{C}$ for $1.5 \mathrm{~min}$, and the reaction mixture was stored at $4{ }^{\circ} \mathrm{C}$ after a final extension at $72^{\circ} \mathrm{C}$ for $7 \mathrm{~min}$.

An appropriate concentration of the NKCC1 or GAPDH competitor was added to each sample. A standard curve was produced by coamplification of the competitor with a series of dilutions of known amounts of NKCC1 or GAPDH cDNA.

After ethanol precipitation, the PCR products were resuspended with TAE, and electrophoretically size fractionated on a $2 \%$ agarose gel in a TAE buffer. After electrophoresis and ethidium bromide staining, signals of PCR products were visualized with a UV transilluminator. The intensity of the bands was measured using a densitometer (Atto, Tokyo, Japan). The ratio of the size of the competitor to cDNA was corrected for differences in molecular weight. In some experiments, the GAPDH expression was examined by RT-competitive PCR as an internal standard. If the expression of GAPDH mRNA was more than $10 \%$ different than that in control, the expression of NKCC1 was corrected according to the GAPDH mRNA expression.

\section{Western blotting}

Western blot analysis was carried out as described earlier. ${ }^{9,19,20}$ Microdissected OMCDs from vasopressin or oxytocin-infused and control rats were added to Eppendorf tubes containing a lysis buffer $\left(0.5 \mathrm{~mm} \mathrm{Na}_{3} \mathrm{VO}_{4}, 1 \mathrm{~mm}\right.$ EDTA, $5 \mathrm{~mm}$ EGTA, $2 \mathrm{~mm}$ DTT, $1 \mathrm{~mm}$ phenylmethyl sulufonylfluoride, $5 \mathrm{~mm}$ glycerophosphatase, $20 \mathrm{~mm}$ HEPES, $10 \mu \mathrm{g} \mathrm{ml}^{-1}$ aprotinine and $10 \mu \mathrm{g} \mathrm{ml}^{-1}$ leupeptine, $\mathrm{pH}$ 7.4). The samples were mixed with a $2 \times$ sample buffer (final concentration $10 \%$ glycerol, 3\% SDS, 5\% 2-mercaptoethanol, $65 \mathrm{~mm}$ DTT, 0.005\% bromophenol blue and $62.5 \mathrm{~mm}$ Tris-HCl, $\mathrm{pH}$ 6.8) and a running buffer $(25 \mathrm{~mm}$ Tris, $192 \mathrm{~mm}$ glycine and $0.1 \% \mathrm{SDS}$ ), and denatured for $5 \mathrm{~min}$ at $95^{\circ} \mathrm{C}$. The samples were electrophoresed on polyacrylamide gels (4-20\% gradation; Daiichi Pure Chemicals, Tokyo, Japan). Dr James Turner kindly provided the rat NKCC1specific antibody. ${ }^{22}$ After electrophoresis, the proteins were transferred electrophoretically onto a nitrocellulose membrane (Immobilon; Millipore, Bedford, MA, USA). The membrane was blocked with a 5\% TBS-T buffer (154 mM $\mathrm{NaCl}, 20 \mathrm{~mm}$ Tris-HCl, $0.1 \%$ Tween 20). The rat NKCC1-specific antibody was diluted 1:500 with a TBS-T solution containing 5\% skimmed milk and incubated overnight at $4^{\circ} \mathrm{C}$. After washing with the TBS-T solution, the proteins were detected using an ECL system (ECL western blot kit; Amersham, Arlington Heights, IL, USA). 
Statistical analysis

Results are expressed as mean \pm s.e.m. Statistical analysis was carried out using Student's $t$-test or analysis of variance (ANOVA) with a Dunnett type multiple compairson, as appropriate. A $P<0.05$ was considered statistically significant. Dr SPSS-II (SPSS, Tokyo, Japan) was used for the analysis.

\section{RESULTS}

Physiological data on vasopressin-infused and control rats

After vasopressin infusion for 4 days, the body weights of the experimental animals were not significantly different from those of saline-infused controls (Table 1) (99.1 \pm 4.3 vs. $80.2 \pm 13.0 \mathrm{~g}$,

Table 1 Physiological data

\begin{tabular}{|c|c|c|}
\hline & Control rats $(n)$ & AVP-treated rats $(n)$ \\
\hline Body weight (g) & $99.1 \pm 4.3(10)$ & $80.2 \pm 13.0(5)$ \\
\hline Urine $\mathrm{pH}$ & $7.7 \pm 0.1(10)$ & $7.2 \pm 0.3^{*}(5)$ \\
\hline Urine osmolality (mosmol kg-1 $\mathrm{H}_{2} \mathrm{O}$ ) & $1031 \pm 109$ (12) & $1655 \pm 222 *(8)$ \\
\hline Serum $\mathrm{Na}\left(\mathrm{mEq} \mathrm{I}^{-1}\right)$ & $133 \pm 8(5)$ & $115 \pm 12^{*}(5)$ \\
\hline Serum $\mathrm{Cl}\left(\mathrm{mEq} \mathrm{I}{ }^{-1}\right)$ & $98 \pm 3(5)$ & $74 \pm 9 *(5)$ \\
\hline Plasma AVP (pg ml-1) & $350 \pm 88(8)$ & $1280 \pm 311 *(6)$ \\
\hline
\end{tabular}

Urine osmolality was measured with an osmometer. Serum sodium and chloride concentrations were measured by autoanalyzer. Plasma concentration of AVP was measured by radioimmunoassay. AVP-treated rats showed lower serum $\mathrm{Na}$ and $\mathrm{Cl}$ concentrations, lower urine $\mathrm{pH}$ and higher plasma AVP level and urine osmolality than control rats. ${ }^{*} P>0.05 \mathrm{vs}$. control rats.
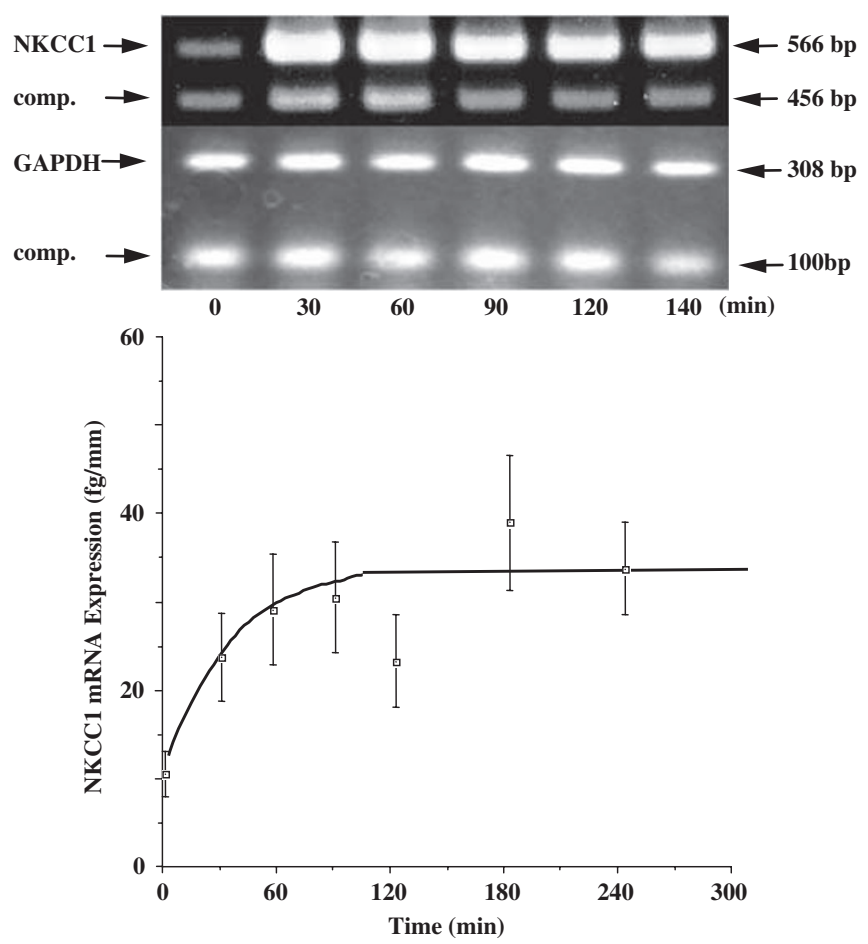

Figure 1 Time course of the effect of hyperosmolality on NKCC1 mRNA expression in OMCD. Micodissected OMCD ( $2 \mathrm{~mm}$ long) was incubated in solution with 690 mosmol kg-1 $\mathrm{H}_{2} \mathrm{O}$ (solution A plus $\mathrm{NaCl}$ ) for $0-240 \mathrm{~min}$ at $37^{\circ} \mathrm{C}$. (Top) A typical example of the ethidium bromide-stained gel. Upper and middle bands show PCR products of NKCC1 mRNA (566 bp) and the competitor (456 bp). The lower bands show GAPDH mRNA (308bp) and the competitor ( $100 \mathrm{bp}$ ) as an internal standard. (Bottom) Time course of the NKCC1 mRNA expression in OMCD. NKCC1 mRNA expression was stimulated by hyperosmolality and reached a plateau after $60 \mathrm{~min}$ incubation $(n=4-10)$. respectively; $P>0.05)$. Urinary $\mathrm{pH}$ was slightly but significantly lower in vasopressin-infused rats $(7.2 \pm 0.3)$ than in controls $(7.7 \pm 0.1$; $P<0.05)$. Urine osmolality was significantly higher in vasopressininfused rats than in controls $\left(1655 \pm 222\right.$ and $1031 \pm 109$ mosmol kg $^{-1}$ $\mathrm{H}_{2} \mathrm{O}$ in vasopressin-infused and control rats, respectively. $n=6$, $P<0.01)$.

Plasma concentrations of sodium and chloride were significantly lower in AVP-treated rats than those in vehicle-treated rats $(\mathrm{Na}$, $115 \pm 12$ and $133 \pm 8 ; \mathrm{Cl}, 74 \pm 9$ and $98 \pm 3$ in vasopressin-treated and control rats, respectively; $P<0.05$ ). The plasma concentration of vasopressin was significantly higher in vasopressin-infused rats than that in controls $\left(1280 \pm 311\right.$ and $350 \pm 88 \mathrm{pg} \mathrm{ml}^{-1}$ in vasopressintreated and controls rats, respectively, $P<0.01$ ). Blood pressure was not changed by the infusion of vasopressin or oxytocin (control: $114 \pm 2 / 86 \pm 3,109 \pm 3 / 80 \pm 4$ and $115 \pm 3 / 85 \pm 4 \mathrm{mmHg}, P>0.05$ for both systolic and diastolic blood pressure for 3 days; vasopressin: $110 \pm 3 / 81 \pm 3, \quad 108 \pm 3 / 86 \pm 4$ and $108 \pm 3 / 87 \pm 3 \mathrm{mmHg}, P>0.05$; oxytocin: $113 \pm 3 / 84 \pm 3,116 \pm 3 / 86 \pm 4$ and $116 \pm 4 / 88 \pm 4 \mathrm{mmHg}$, $P>0.05$ on days 0,2 and 4 after the infusion, respectively; $n=4-7$ for each measurement).

Effect of hyperosmolality on NKCC1 mRNA expression in OMCD To determine the time course of the stimulation of NKCC1 mRNA expression by hyperosmolality, the microdissected OMCD samples were incubated in 690 mosmol kg $\mathrm{H}_{2} \mathrm{O}$ solution for different periods. The expression of NKCC1 mRNA in OMCD was stimulated by hyperosmolality and reached a plateau after $60 \mathrm{~min}$ incubation

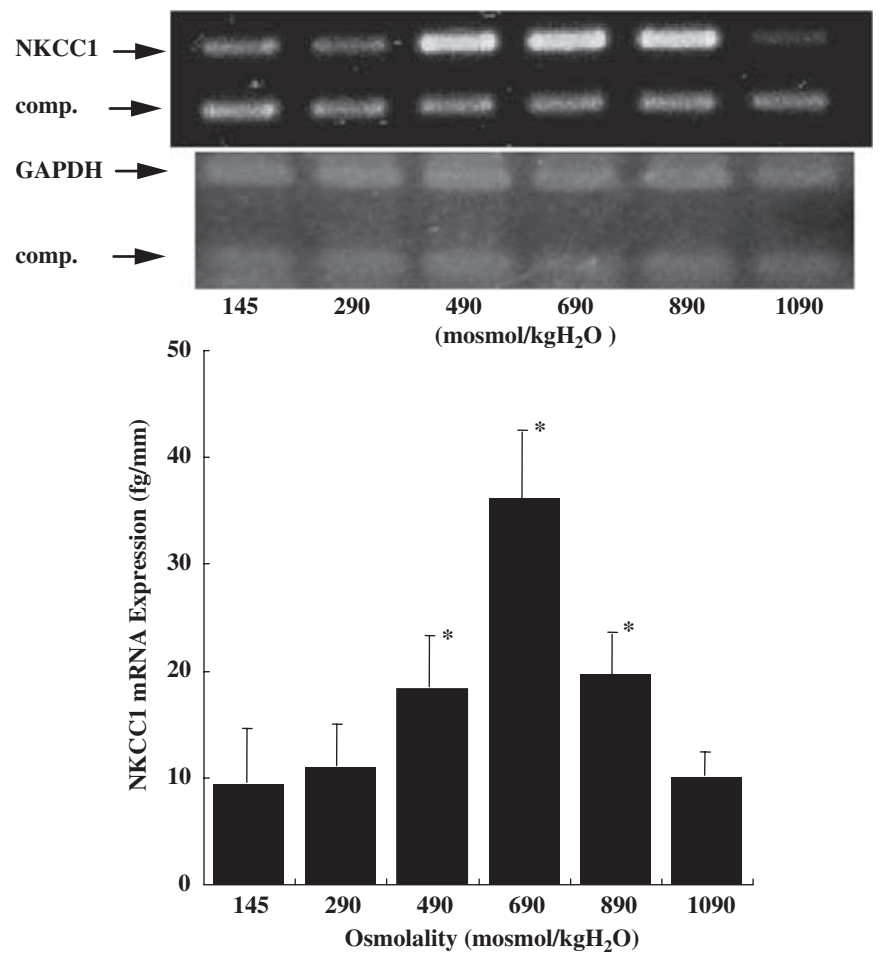

Figure 2 The effect of hypo- and hyperosmolality on NKCC1 mRNA expression in OMCD. OMCD was incubated in hypo- or hyperosmotic solutions with different osmolalities. (Top) A typical example of the ethidium bromide-stained gel. (Bottom) The effect of osmolality on NKCC1 mRNA expression in OMCD. NKCC1 mRNA expression was most abundant at 690 mosmol kg-1 $\mathrm{H}_{2} \mathrm{O}$. A further increase of the osmolality decreased the expression. ${ }^{*} P<0.05$ vs. 290 mosmol kg ${ }^{-1} \mathrm{H}_{2} \mathrm{O}(n=6-9)$. 

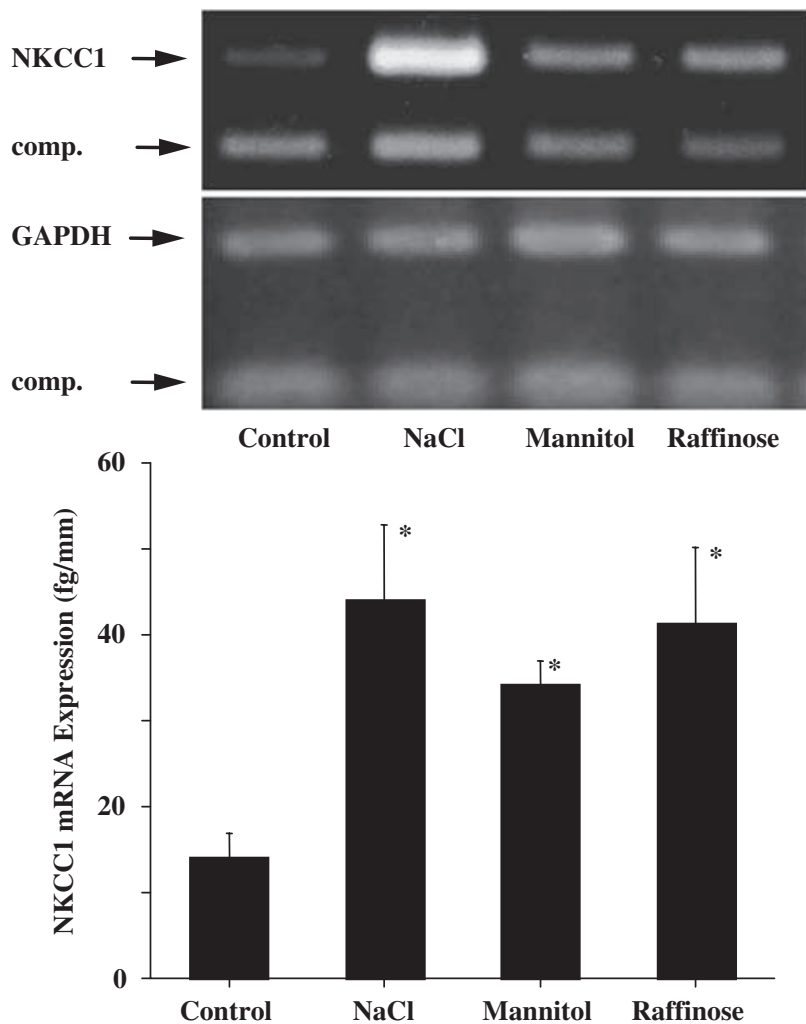

Figure 3 The effect of hyperosmolality induced by different drugs on NKCC1 mRNA expression in OMCD. OMCD was incubated in a hyperosmotic solution prepared by the addition of $\mathrm{NaCl}$, mannitol or raffinose. (Top) A typical example of the ethidium bromide-stained gel. (Bottom) The effect of hyperosmolality on NKCC1 mRNA expression in OMCD. Mannitol and raffinose also stimulated NKCC1 mRNA expression in OMCD. ${ }^{*} P<0.05$ vs. control (290 mosmol kg-1 $\left.\mathrm{H}_{2} \mathrm{O}\right)(n=6-9)$.

(Figure 1). Accordingly, $60 \mathrm{~min}$ was used as the incubation time for the following experiments.

Next, to determine the osmolality resulting in maximal stimulation of NKCC1 mRNA expression, microdissected OMCD samples were incubated in solutions with different osmolalities, which were achieved by adding $\mathrm{NaCl}$. The NKCC1 mRNA expression was highest at 690 mosmol kg $\mathrm{H}_{2} \mathrm{O} \quad(9.5 \pm 5.1,11.1 \pm 3.8,18.5 \pm 4.8,36.5 \pm 7.0$, $18.8 \pm 4.6$ and $10.0 \pm 2.3 \mathrm{fg} \mathrm{mm}^{-1}$ in $145,290,490,690,890$ and 1090 mosmol kg ${ }^{-1} \mathrm{H}_{2} \mathrm{O}$, respectively; $n=6-9 ; P<0.05$, Figure 2$)$. It is noteworthy that the NKCC1 mRNA expression at 1,090 mosmol kg-1 $\mathrm{H}_{2} \mathrm{O}$ did not differ from that at 290 mosmol kg-1 $\mathrm{H}_{2} \mathrm{O}$. Thereafter, to determine whether the stimulation of NKCC1 mRNA expression was caused by $\mathrm{NaCl}$ or by hyperosmolality; a hypertonic solution was prepared by the addition of mannitol and raffinose. Hyperosmolality by mannitol and raffinose also increased the NKCC1 mRNA expression, suggesting that hyperosmolality itself stimulated NKCC1 mRNA expression (NKCC1 mRNA expression: $14.0 \pm 2.8,44.2^{\star} \pm 9.2$, $33.6^{\star} \pm 3.8$ and $40.9^{\star} \pm 8.9$ in the control, $\mathrm{NaCl}$, mannitol and raffinose groups, respectively; ${ }^{\star} P<0.05 v$ s. control; Figure 3 ).

\section{Effect of vasopressin on NKCC1 mRNA expression in OMCD} in vitro

Microdissected OMCD was incubated for $60 \mathrm{~min}$ in solution with different concentrations of AVP. AVP in concentrations from $10^{-10}$ to $10^{-7} \mathrm{M}$ increased the NKCC1 mRNA expression by $70-90 \%$ (Figure 4). In contrast, the incubation of microdissected OMCD with oxytocin

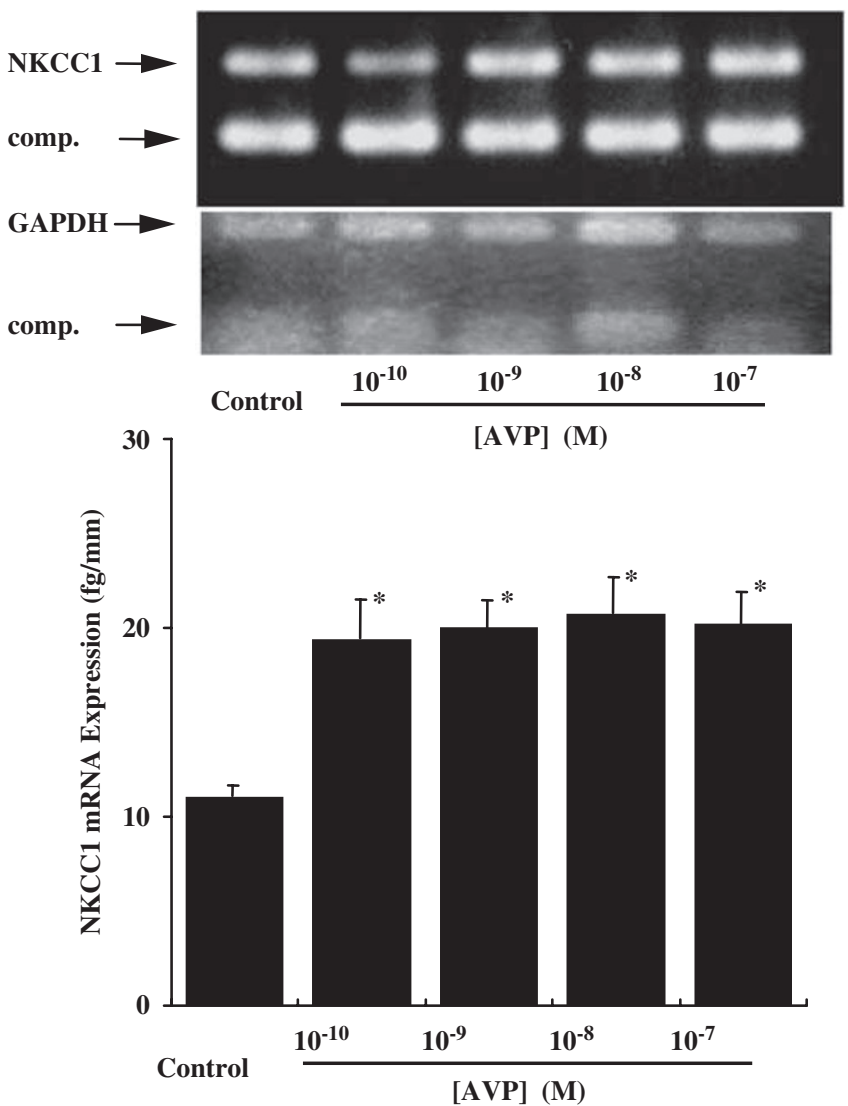

Figure 4 The dose dependency of the effect of AVP on NKCC1 mRNA expression in OMCD. OMCD was incubated with different concentrations of AVP for $60 \mathrm{~min}$ at $37^{\circ} \mathrm{C}$. (Top) A typical example of the ethidium bromidestained gel. (Bottom) The effect of AVP on NKCC1 mRNA expression in OMCD. AVP stimulated NKCC1 mRNA in OMCD in vitro. $n=5,{ }^{*} P<0.05$ vs. control.

did not result in any change in the NKCC1 mRNA expression (Figure 5).

\section{Effect of vasopressin on NKCC1 mRNA expression in OMCD} in vivo

Administration of AVP to rats in vivo increased the NKCC1 mRNA expression by $80 \%\left(27.5 \pm 3.9\right.$ and $46.5 \pm 8.9 \mathrm{fg} \mathrm{mm}^{-1}$ in vehicle and AVP-treated rats, respectively; $n=12 ; \quad P<0.05$; Figure 6).

Effect of oxytocin on NKCC1 mRNA expression in OMCD in vivo Oxytocin injected into rats in vivo caused a stimulation of the NKCC1 mRNA expression by $36 \%\left(11.4 \pm 1.3\right.$ and $15.5 \pm 2.9 \mathrm{fg} \mathrm{mm}^{-1}$ in vehicle and oxytocin-injected rats, respectively; $n=8 ; P<0.05$; Figure 7).

\section{Effect of AVP on NKCC1 protein expression in vivo}

The NKCC1 protein was detected at $170 \mathrm{kDa}$ by western blotting. Administration of AVP in vivo increased the NKCC1 protein expression in OMCD by $135 \%$ (Figure 8 ).

\section{DISCUSSION}

The purpose of this study was to determine the mechanisms by which dehydration activates NKCC1 expression. We focused on AVP and hyperosmolality, as dehydration causes increases in plasma AVP levels 

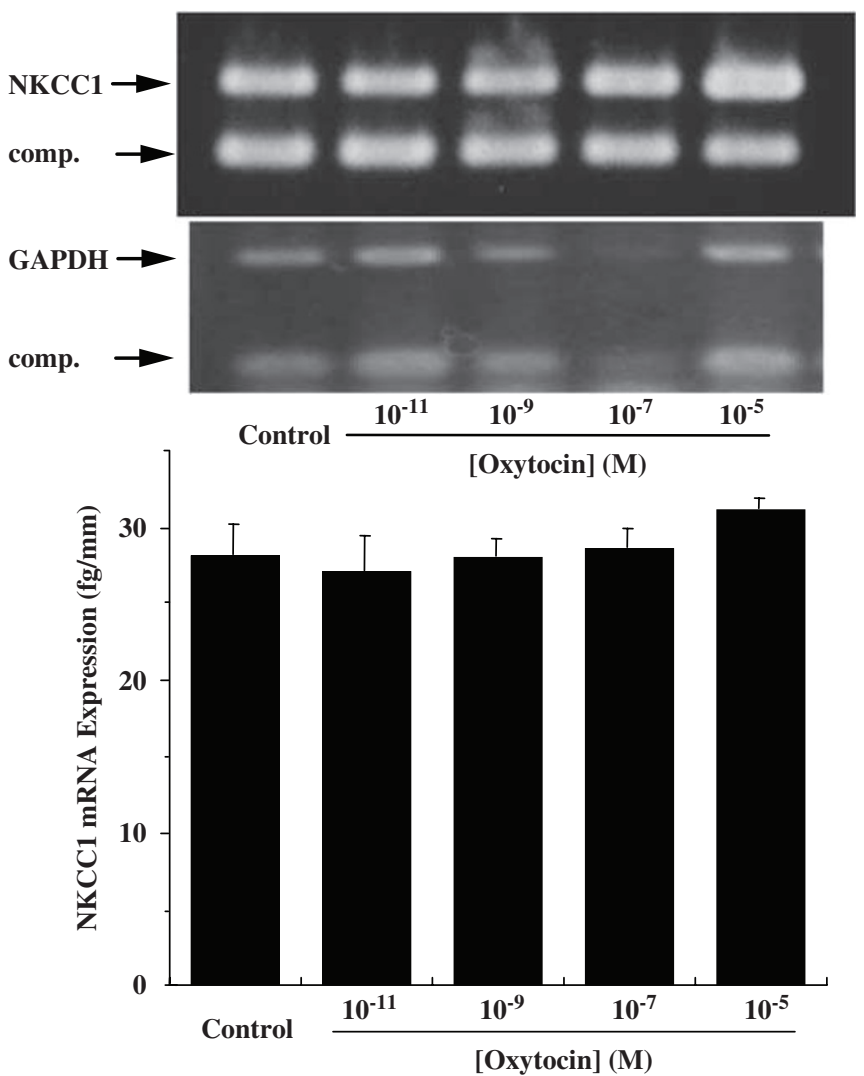

Figure 5 The effect of oxytocin on NKCC1 mRNA expression in OMCD in vitro. OMCD was incubated with different concentrations of oxytocin for 60 min. (Top) A typical example of ethidium bromide-stained gel. (Bottom) The effect of oxytocin on NKCC1 mRNA expression in OMCD in vitro. Unlike AVP, oxytocin did not affect NKCC1 mRNA expression in OMCD $(n=7)$.

and in the osmolality of plasma and the renal medullary interstitium. To determine the effect of AVP and hyperosmolality on NKCC1 expression, microdissected OMCD was incubated with AVP, oxytocin or in hyperosmotic solutions. Vasopressin was also administrated to rats in vivo. NKCC1 mRNA and protein expressions were stimulated by vasopressin (in vitro and in vivo) and hyperosmolality in our study, suggesting that both play an important role in the activation of NKCC1 by dehydration.

The findings that urine osmolality and plasma vasopressin concentration were higher in vasopressin-infused rats than in controls indicated that an appropriate concentration of vasopressin was given in our study. Urinary $\mathrm{pH}$ was significantly lower in vasopressininfused rats than in controls, suggesting the stimulation of proton secretion, at least in the collecting ducts, by vasopressin. Vasopressin is known to inhibit bicarbonate absorption (proton secretion) in the thick ascending limb of Henle's loop, and to stimulate such absorption in the collecting ducts. ${ }^{12,24}$ Chronic administration of vasopressin has also been shown to stimulate NKCC2 expression in the thick ascending limbs of Henle's loop, ${ }^{12}$ in $\mathrm{NH}_{4}{ }^{+}$absorption through NKCC2 and in the accumulation of $\mathrm{NH}_{4}^{+}$in the medullary interstitium. Low luminal $\mathrm{pH}$ caused by vasopressin-induced proton secretion stimulates the $\mathrm{NH}_{3}$ trap by non-ionic diffusion in the collecting ducts. NKCC1 is known to secrete $\mathrm{NH}_{4}{ }^{+8,25}$ Under normal conditions, the secretion of $\mathrm{NH}_{4}{ }^{+}$or sodium by NKCC1 is low. ${ }^{25}$ But the amount of $\mathrm{NH}_{4}{ }^{+}$secretion by NKCC1 in dehydration or in metabolic acidosis is not known. The finding that NKCC1 is activated by dehydration and

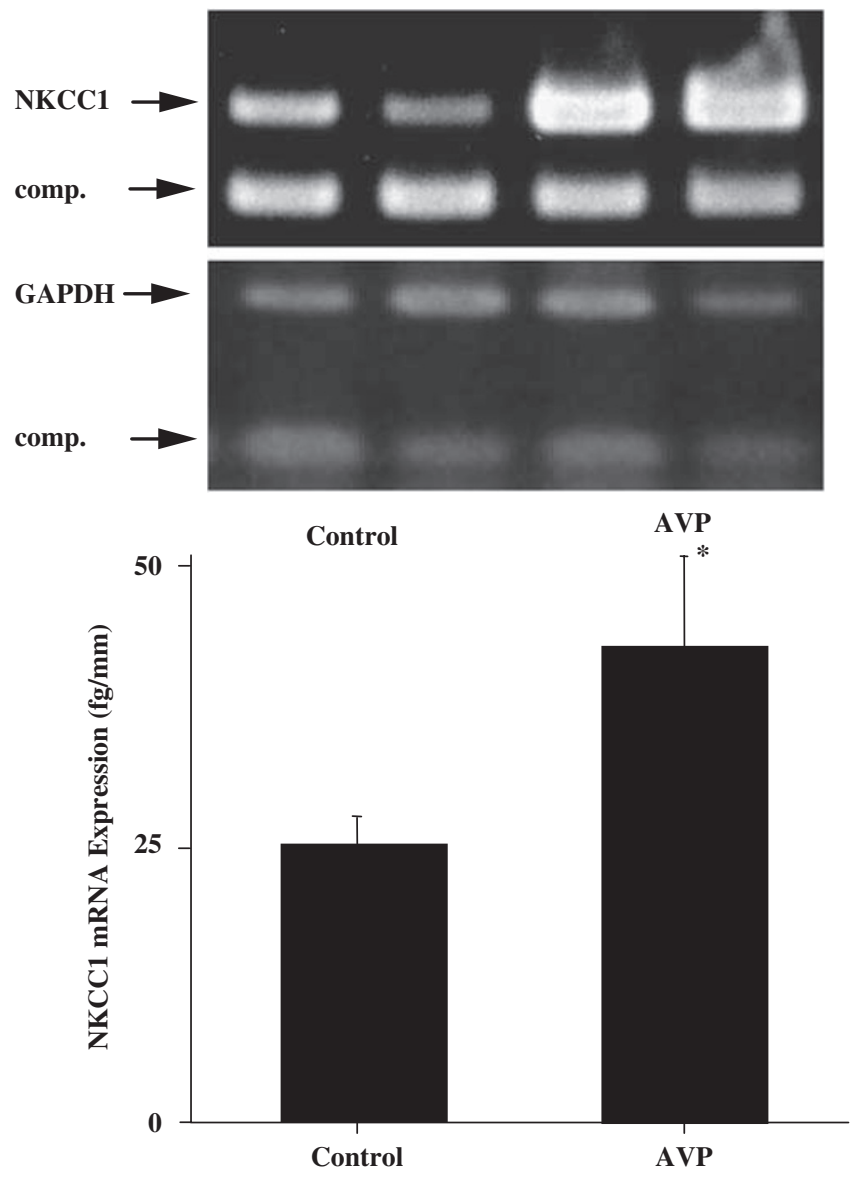

Figure 6 The effect of AVP on NKCC1 mRNA expression in OMCD in vivo. $\mathrm{OMCD}$ was dissected from controls or AVP-infused (4 days) rats. (Top) A typical example of the ethidium bromide- stained gel. (Bottom) The effect of AVP on NKCC1 mRNA expression in OMCD in vivo. AVP in vivo stimulated NKCC1 mRNA expression in OMCD. $n=12,{ }^{*} P<0.05$ vs. control.

metabolic acidosis suggests that $\mathrm{NH}_{4}{ }^{+}$secretion could be increased through NKCC1 in dehydration and metabolic acidosis. ${ }^{9}$

The NKCC1 mRNA expression was stimulated by incubation in a hyperosmotic solution. In dehydration or under a high concentration of plasma AVP, a large axial osmolality gradient in the medullary interstitium induces high urine osmolality. The high interstitial osmolality causes epithelial cells to shrink, which may in turn stimulate NKCC1 activity and expression to recover cell volume. It has been reported that hypertonic cell shrinkage increases electrolyte influx by NKCC1 in duck RBC, ${ }^{17}$ in Ehrlich ascites cells ${ }^{15}$ and in cultured kidney cells (IMCD-3) ${ }^{26}$ for regulatory volume increase. In contrast, an isolated tubule perfusion technique showed cell swelling of collecting ducts by exposure to vasopressin. ${ }^{27} \mathrm{~A}$ larger increase in water permeability of the luminal membrane than that of the basolateral membrane has been speculated for the mechanism of cell swelling. Chou et al. ${ }^{27}$ reported that AVP-induced cell height increase is dependent on solute uptake by NKCC1, but is not dependent on apical water entry into an isolated perfused rat inner medullary collecting duct (IMCD). Although our data show that hyperosmolality by mannitol and raffinose also increased the NKCC1 mRNA expression, mannitol-induced hyperosmolality did not cause cell swelling by NKCC1 in their study. ${ }^{27}$ They observed a very acute effect of $\mathrm{NaCl}$ or hyperosmolality on NKCC1 in isolated perfused IMCD. In contrast, we incubated OMCD for $60 \mathrm{~min}$. An increase in water flux through a 

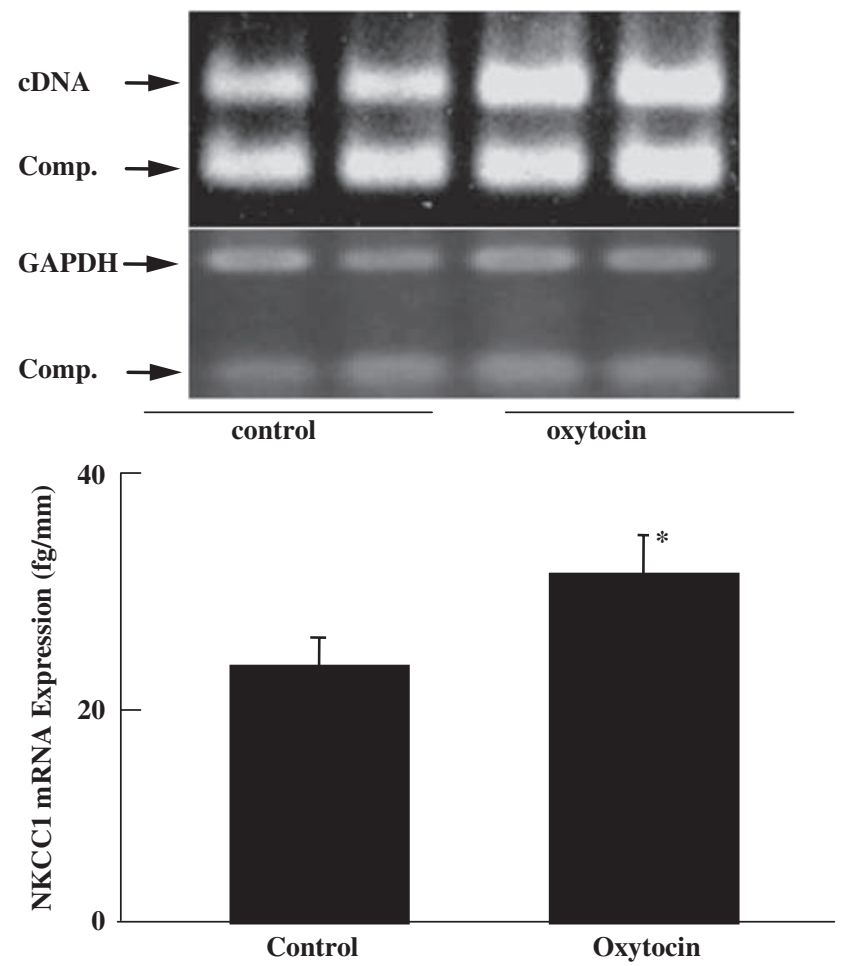

Figure 7 The effect of oxytocin on NKCC1 mRNA expression in OMCD in vivo. OMCD from controls or oxytocin-infused (4 days) rats was used. (Top) A typical example of the ethidium bromide-stained gel. (Bottom) Summary of the effect of oxytocin on NKCC1 mRNA expression in OMCD in vivo. Oxytocin caused a small increase of NKCC1 mRNA expression in $\operatorname{OMCD}(n=9) .{ }^{*} P<0.05$ vs. control.

water channel causes a decrease in intracellular $\mathrm{NaCl}$ concentration, which subsequently stimulates NKCC1 expression. These data clearly indicate that NKCC1 participates in acute regulatory volume increase, particularly in the presence of AVP. Renal medullary cells are also known to increase intracellular osmolytes in defense against chronic outer cellular hyperosmolality. The roles of these osmolytes in the chronic activation of NKCC1 must be examined further.

The NaCl-induced expression of NKCC1 mRNA was most abundant at 690 mosmol kg-1 $\mathrm{H}_{2} \mathrm{O}$, and a further increase of osmolality did not further increase the expression. 690 mosmol kg-1 $\mathrm{H}_{2} \mathrm{O}$ might be a reasonable estimate of the osmolality of the luminal fluid of OMCD under normal conditions. If the same experiments were carried out using IMCD, the maximal stimulation may be observed at a much higher osmolality. Incubation of trabecular meshwork cells in a hypotonic solution is reported to introduce the intracellular chloride concentration $([\mathrm{Cl}] \mathrm{i})$ decrease resulting from osmotic dilution of intracellular solutes, plus perhaps a volume regulatory loss of $\mathrm{KCl}$ from the cells. ${ }^{28}$ In that study, the decrease of $[\mathrm{Cl}] \mathrm{i}$ stimulated NKCC1 cotransporter activity measured as bumetanidesensitive $\mathrm{K}$ influx. However, this stimulating effect of the decrease in $[\mathrm{Cl}] \mathrm{i}$ was additive with the hyperosmolality-induced activation of NKCC1 activity. Thus, the role of $[\mathrm{Cl}] \mathrm{i}$ may be different between isotonic and hypertonic conditions. The volume-sensitive phosphorylation of $\mathrm{NKCC1}$ by $\mathrm{c}$-Jun $\mathrm{NH}_{2}$-terminal kinase and the phosphorylation of the myosin light chains may play some roles in hyperosmolality-induced upregulation of NKCC1. ${ }^{29,30}$ The AVP-stimulated cAMP generation in OMCD from dehydrated rats was increased by incubation in the hypertonic medium,
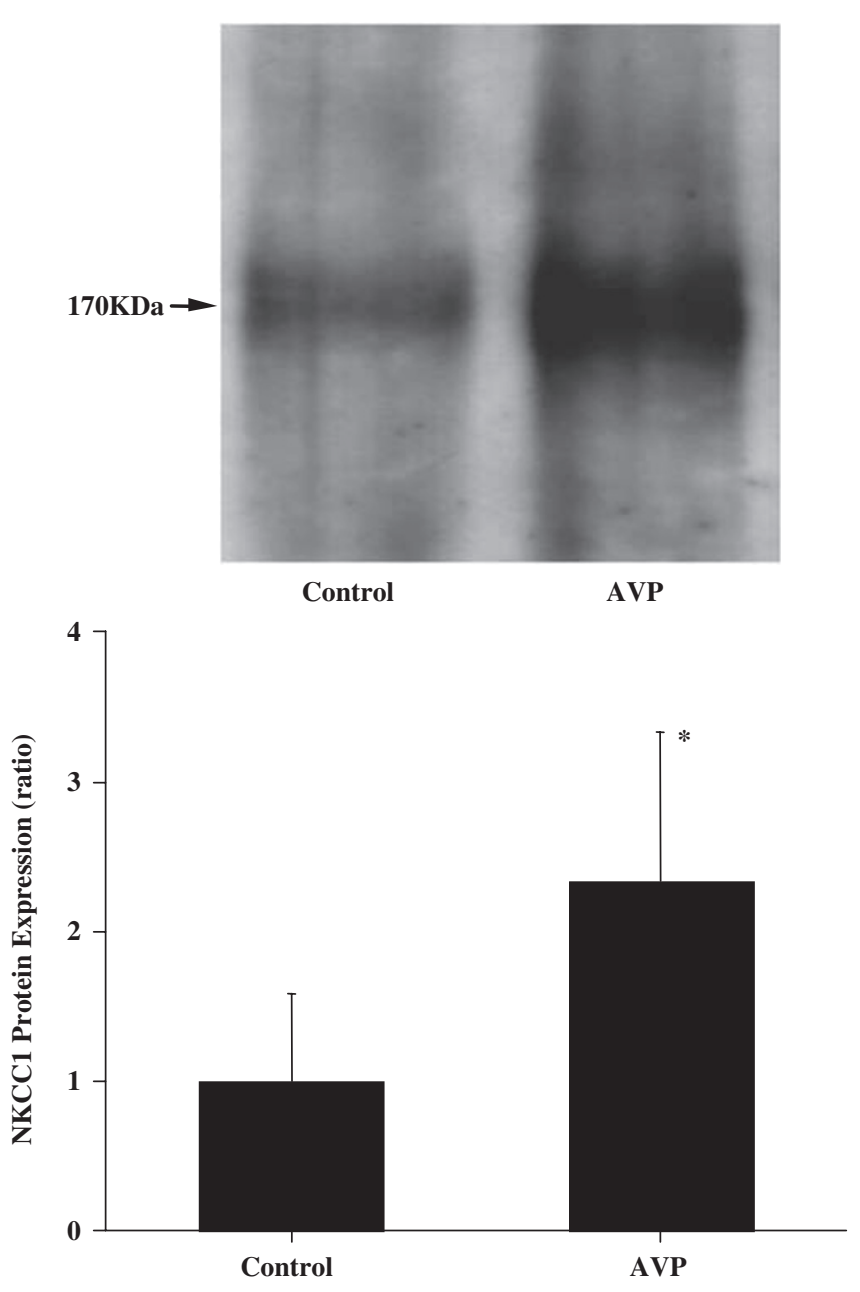

Figure 8 The effect of AVP on NKCC1 protein expression in OMCD in vivo. AVP was administered to rats by an osmotic mini-pump for 4 days. (Top) A typical example of western blotting. Single band was observed at $70 \mathrm{kDa}$. (Bottom) The effect of AVP on NKCC1 expression in OMCD in vitro. AVP in vivo stimulated NKCC1 protein expression in OMCD. The NKCC1 protein expression was expressed as a ratio to the control $(n=6) .{ }^{*} P<0.05$ vs. control.

although such an increase was not observed in the medullary thick ascending limbs. ${ }^{31}$ The lack of a water channel in the medullary thick ascending limbs may be responsible for such a difference between OMCD and the medullary thick ascending limbs.

NKCC1 was activated by vasopressin in vivo and in vitro in our study. These data suggest that AVP directly stimulated the NKCC1 expression. AVP may also stimulate NKCC1 expression indirectly by increasing the osmolality of the plasma and medullary interstitium. In contrast, oxytocin increased the NKCC1 mRNA expression in $\mathrm{OMCD}$ in vivo but not in vitro. Oxytocin is known to increase osmotic water permeability in collecting ducts by binding to both oxytocin and V2 receptors, because the structure of oxytocin is very similar to vasopressin. The concentration of oxytocin in normal well-hydrated SD rats is $\sim 5 \mathrm{pm}^{32}$ The plasma concentration of oxytocin used in this study is estimated to be more than 20 pM. If AVP stimulates NKCC1 expression through V2 receptors, ${ }^{33}$ we might speculate that oxytocin would also increase NKCC1 expression. In this study, however, the NKCC1 expression was not significantly increased by the incubation of OMCD with oxytocin. The stimulation of NKCC1 mRNA by oxytocin in vivo could be caused by an indirect 
effect on oxytocin, probably through the action of the $\mathrm{V} 2$ receptor as reported recently. ${ }^{34}$

NKCC1-deficient mice have been generated and analyzed. These mice exhibit deafness and loss of their sense of balance because of impaired transepitherial $\mathrm{K}^{+}$movement of the inner ear. ${ }^{35,36}$ Those mice who were completely lacking in NKCC1 also seemed to show hypotension and retarded growth. NKCC1 deficiency is reported to be associated with greater blood pressure increase during high salt intake at night and greater blood pressure decrease during low salt intake during the day. ${ }^{37}$ Although hypereninemic hyperaldosteronism was reported, the precise mechanism of altered salt sensitivity in NKCC1deficient mice is not known. Although the participation of NKCC1 in sodium transport is negligible, its participation in the renin-angiotensin-aldosterone system has been speculated. Further investigations will, therefore, be needed to determine the function of NKCC1 in the kidneys of these mutant mice.

In summary, our data suggest that AVP and hyperosmolality stimulate the NKCC1 expression in OMCD. AVP stimulates NKCC1 activity directly and indirectly through an increase in plasma and medullary interstitial osmolality. It is concluded that the increase of plasma AVP level in dehydration may play a crucial role in the activation of NKCC1 in the kidneys.

1 Russell JM. Sodium-potassium-chloride cotransport. Physiol Rev 2000; 80: 211-276.

2 Gamba G, Miyanoshita A, Lombardi M, Lytton J, Lee W-S, Hedigar MA, Hebert SC. Molecular cloning, primary structure, and characterization of two members of the mammalian electroneutral sodium-(potassium)-chloride cotransporter family expressed in kidney. J Biol Chem 1994; 269: 17713-17722.

3 Xu J-C, Lytle C, Zhu TT, Payne JA, Benz Jr E. Forbush III B. Molecular cloning and functional expression of the bumetanide-sensitive $\mathrm{Na}-\mathrm{K}-\mathrm{Cl}$ cotransporter. Proc Natl Acad Sci USA 1994; 91: 2291-2295.

4 Payne JA, Xu JC, Haas M, Lytle CY, Ward D, Forbush III B. Primary structure, functional expression, and chromosomal localization of the bumetanide-sensitive Na-K-Cl cotransporter in human colon. J Biol Chem 1995; 270: 17977-17985.

5 Evans RL, Turner RJ. New insights into the upregulation and function of the salivary $\mathrm{Na}^{+}-\mathrm{K}^{+}-2 \mathrm{Cl}^{-}$cotransporter. Eur J Morphol 1998; 36: 142-146.

6 Lytle C, Xu JC, Biemesderfer D, Forbush III B. Distribution and diversity of Na-K-Cl cotransport proteins: a study with monoclonal antibodies. Am J Physiol 1995; 269 (Cell Physiol 38): C1496-C1505

7 Ginns SM, Knepper MA, Ecelbarger CA, Terris J, He X, Coleman RA, Wade JB. Immunolocalization of the secretory isoform of $\mathrm{Na}-\mathrm{K}-\mathrm{Cl}$ cotransporter in rat renal intercalated cells. J Am Soc Nephrol 1996; 7: 2533-2542.

8 Wall SM, Fischer MP. Contribution of the $\mathrm{Na}(+)-\mathrm{K}(+)-2 \mathrm{Cl}(-)$ cotransporter (NKCC1) to transepithelial transport of $\mathrm{H}(+), \mathrm{NH}(4)(+), \mathrm{K}(+)$, and $\mathrm{Na}(+)$ in rat outer medullary collecting duct. J Am Soc Nephrol 2002; 13: 827-835.

9 Ikebe M, Nonoguchi H, Nakayama Y, Tashima Y, Tomita K. Upregulation of the secretory-type $\mathrm{Na}(+) / \mathrm{K}(+) / 2 \mathrm{Cl}(-)$-cotransporter in the kidney by metabolic acidosis and dehydration in rats. J Am Soc Nephrol 2001; 12: 423-430.

10 Nonoguchi H, Owada A, Kobayashi N, Takayama M, Terada Y, Koike J, Ujiie K, Marumo F, Sakai T, Tomita K. Immunohistochemical localization of V2 vasopressin receptor along the nephron and functional role of luminal V2 receptor in terminal inner medullary collecting ducts. J Clin Invest 1995; 96: 1768-1778.

11 Rosenthal W, Seibold A, Antaramian A, Lonergan M, Arthus MF, Hendy GN, Birnbaumer $M$, Bichet DG. Molecular identification of the gene responsible for congenital nephrogenic diabetes insipidus. Nature 1992; 359: 233-235.

12 Knepper MA, Kim GH, Fernandez-Llama P, Ecelbarger CA. Regulation of thick ascending limb transport by vasopressin. J Am Soc Nephrol 1999; 10: 628-634.

13 Brock TA, Brugnara C, Canessa M, Gimbrone MA, Jr. Bradykinin and vasopressin stimulate $\mathrm{Na}^{+}-\mathrm{K}^{+}-\mathrm{Cl}^{-}$cotransport in cultured endothelial cells. Am J Physiol 1986; 250 (Cell Physiol 19): C888-C895.
14 Amsler K, Donahue JJ, Slayman CW, Adelberg EA. Stimulation of bumetanide-sensitive $\mathrm{K}^{+}$transport in Swiss 3T3 fibroblasts by serum and mitogenic hormones. J Cell Physiol 1985; 123: 257-263.

15 Jensen BS, Hoffmann EK. Hypertonicity enhances expression of functional $\mathrm{Na}^{+} / \mathrm{K}^{+} / 2 \mathrm{Cl}^{-}$ cotransporters in Ehrlich ascites tumour cells. Biochim Biophys Acta 1997; 1329: $1-6$.

16 Levinson C. Regulatory volume increase in Ehrich ascites tumor cells. Biochem Biophys Acta 1990; 1021: 1-8.

17 Lytle C. A volume-sensitive protein kinase regulates the $\mathrm{Na}-\mathrm{K}-2 \mathrm{Cl}$ cotransporter in duck red blood cells. Am J Physiol 1998; 274 (Cell Physiol 43): C1002-C1010.

18 Lytle C, Forbush III B. The Na-K-Cl cotransport protein of shark rectal gland. II. Regulation by direct phosphorylation. J Biol Chem 1992; 267: 25438-25443.

19 Nakayama Y, Nonoguchi H, Kiyama S, Ikebe M, Tashima Y, Shimada K, Tanzawa K, Tomita K. Intranephron distribution and regulation of endothelin-converting enzyme-1 in cyclosporin A-induced acute renal failure in rats. J Am Soc Nephrol 1999; 10: 562-571.

20 Machida K, Wakamatsu S, Izumi Y, Yosifovska T, Matsuzaki T, Nakayama Y, Kohda Y, Inoue T, Saito H, Tomita K, Nonoguchi H. Down-regulation of V2 vasopressin receptor in dehydration: mechanisms and the role of renal prostaglandin synthesis. Am J Physiol Renal Physiol 2007; 292: F1274-F1282.

21 Machida K, Nonoguchi H, Wakamatsu S, Inoue H, Yosifovska T, Inoue T, Tomita K. Acute regulation of the epithelial sodium channel gene by vasopressin and hyperosmolality. Hypertens Res 2003; 26: 629-634.

22 Moore-Hoon ML, Turner RJ. Molecular and topological characterization of the rat parotid $\mathrm{Na}^{+}-\mathrm{K}^{+}-2 \mathrm{Cl}^{-}$cotransporter1. Biochim Biophys Acta 1998; 1373: 261-269.

23 Fort P, Marty L, Picchaczyk M, Sabrouly SE, Dani C, Jeanteur P, Blanchard JM. Various rat adult tissues express only one major mRNAspecies from the glyceraldehydes-3phosphate dehydrogenase multigene family. Nucleic Acids Res 1985; 13: 1431-1442.

24 Tomita K, Pisano JJ, Burg MB, Knepper MA. Effects of vasopressin and bradykinin on anion transport by the rat cortical collecting duct. Evidence for an electroneutral sodium chloride transport pathway. J Clin Invest 1986; 77: 136-141.

25 Wall SM, Trinh HN, Woodward KE. Heterogeneity of $\mathrm{NH}^{4+}$ transport in mouse inner medullary collecting duct cells. Am J Physiol 1995; 269 (Renal Fluid Electrolyte Physiol 38): F536-F544.

26 Anzai N, Izumida I, Kobayashi Y, Kawahara K. Roles of vasopressin and hypertonicity in basolateral $\mathrm{Na} / \mathrm{K} / 2 \mathrm{Cl}$ cotransporter expression in rat kidney inner medullary collecting duct cells. Jpn J Physiol 1999; 49: 201-206.

27 Chou CL, Yu MJ, Kassai EM, Morris RG, Hoffert JD, Wall SM, Knepper MA. Role of basolateral solute uptake via NKCC1 and of myosin II in vasopressin-induced cell swelling in inner medullary collecting duct. Am J Physiol Renal Physiol 2008; 295: F192-F201.

28 Putney L, Vibat CR, O’Donnell ME. Intracellular $\mathrm{Cl}$ regulates Na-K-Cl cotransport activity in human trabecular meshwork cells. Am J Physiol 1999; 277 (Cell Physiol 46): C373-C383.

29 Klein JD, Lamitina ST, O'Neill WC. JNK is a volume-sensitive kinase that phosphorylates the Na-K-2Cl cotransporter in vitro. Am J Physiol 1999; 277 (Cell Physiol 46): C425-C431.

30 Hecht G, Koutsouris A. Myosin regulation of NKCC1: effects on cAMP-mediated $\mathrm{Cl}$ secretion in intestinal epithelia. Am J Physiol 1999; 277 (Cell Physiol 46): C441-C447.

31 Sakuma Y, Nonoguchi H, Takayama M, Yang T, Terada Y, Inoue T, Nakayama Y, Kohda Y, Sasaki S, Tomita K. Differential effects of hyperosmolality on Na-K-ATPase and vasopressin-dependent cAMP generation in the medullary thick ascending limb and outer medullary collecting duct. Hypertens Res 2005; 28: 671-679.

32 Chou CL, DiGiovanni SR, Mejia R, Nielsen S, Knepper MA. Oxytocin as an antidiuretic hormone. I. Concentration dependence of action. Am J Physiol 1995; 269 (Renal Fluid Electrolyte Physiol 38): F70-F77.

33 Chou CL, DiGiovanni SR, Luther A, Lolait SJ, Knepper MA. Oxytocin as an antidiuretic hormone II role of V2 vasopressin receptor. Am J Physiol 1995; 269 (Renal Fluid Electrolyte Physiol 38): F78-F85.

34 Li C, Wang W, Summer SN, Westfall TD, Brooks DP, Falk S, Schrier RW. Molecular mechanisms of antidiuretic effect of oxytocin. J Am Soc Nephrol 2008; 19: 225-232.

35 Delpire E, Lu J, England R, Dull C, Thorne T. Deafness and imbalance associated with inactivation of the secretory Na-K-2Cl co-transporter. Nat Genet 1999; 22: 192-195.

36 Flagella M, Clarke LL, Miller M L, Erway LC, Giannella RA, Andringa A, Gawenis LR, Kramer J, Duffy JJ, Doetschman T, Lorenz JN, Yamoah EN, Cardell EL, Shull GE. Mice lacking the basolateral Na-K-2Cl cotransporter have impaired epithelial chloride secretion and are profoundly deaf. J Biol Chem 1999; 274: 26946-26955.

37 Kim SM, Eisner C, Faulhaber-Walter R, Mizel D, Wall SM, Briggs JP, Schnermann J. Salt sensitivity of blood pressure in NKCC1-deficient mice. Am J Physiol Renal Physiol 2008; 295: F1230-F1238. 